\title{
Additional records of Tettigoniidae from Arunachal Pradesh, India
}

\author{
G. Srinivasan ${ }^{1} \&$ D. Prabakar ${ }^{2}$ \\ 1,2 Zoological Survey of India, 535, M-Block, New Alipore, Kolkata, West Bengal 700053, India \\ Email: ${ }^{1}$ zsisamy@rediffmail.com (corresponding author), ${ }^{2}$ dprabakar14@gmail.com
}

Date of publication (online): 26 November 2012 Date of publication (print): 26 November 2012 ISSN 0974-7907 (online) | 0974-7893 (print)

Editor: R.K. Avasthi

Manuscript details:

Ms \# 02927

Received 25 August 2011

Final received 03 October2012

Finally accepted 17 October 2012

Citation: G. Srinivasan \& D. Prabakar (2012) Additional records of Tettigoniidae from Arunachal Pradesh, India. Journal of Threatened Taxa 4(14): 3255-3268.

Copyright: @ G. Srinivasan \& D. Prabakar 2012. Creative Commons Attribution 3.0 Unported License. JoTT allows unrestricted use of this article in any medium for non-profit purposes, reproduction and distribution by providing adequate credit to the authors and the source of publication.

Author Details: Dr. G. SRINIVASAN is working as Scientist-C in Zoological Survey of India, Kolkata. His area of research interest are in the Bio-systematic studies of short horned and long horned grasshoppers (Orthoptera), Phasmids and Vespidae (Hymenoptera)

SHRI. D. PrabakAR working as Assistant Zoologis at Zoological Survey of India, Southern Regional Centre, Chennai. His area of research interest is in the bio-systematic studies of grasshoppers (Orthoptera).

Author Contribution: See end of this article.

Acknowledgements: We are grateful to Dr. K. Venkataraman, Director, Zoological Survey of India, Kolkata for providing facilities to carry out the work. We are also thankful to Dr. G. Maheswaran, Officer-in-Charge, Arunachal Pradesh Field Centre, Zoological Survey of India, Itanagar for providing the specimens on loan for our studies.

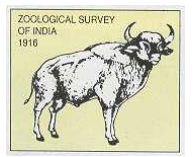

urn:Isid:zoobank.org:pub:FFB58E61-65374F34-BC8A-8453F8C2F05E

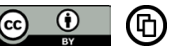

OPEN ACCESS | FREE DOWNLOAD
Abstract: Ten species of Tettigoniids under 10 genera belonging to five subfamilies of the family Tettigoniidae from Arunachal Pradesh are discussed of which five species are new records to India and nine species are new records to Arunachal Pradesh.

Keywords: Arunachal Pradesh, Chloracris, Khaoyaiana, Phyllozelus, Pseudophyllus, Onomarchus, Orthoptera, Tettigoniidae, Trachyzulpha,

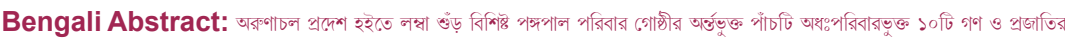

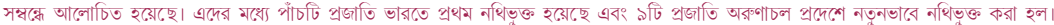

The state of Arunachal Pradesh is located in northeastern India, situated between $26^{0} 28^{\prime}-29^{0} 30^{\prime} \mathrm{N}$ and $91^{0} 30^{\prime}-97^{0} 30^{\prime} \mathrm{E}$ and borders the states of Assam and Nagaland to the south, and shares international borders with Bhutan in the west, Myanmar in the east and the People's Republic of China (PRC) in the north. Arunachal Pradesh is covered by the Himalaya. However, parts of Lohit, Changlang and Tirap are covered by the Patkai Hills. Kangto, Nyegi Kangsang, the main Gorichen Peak and the eastern Gorichen Peak are some of the highest peaks in this region of the Himalaya. At the lowest elevations, essentially at Arunachal Pradesh's border with Assam, is Brahmaputra Valley with its semievergreen forests. Much of the state, including the Himalayan foothills and the Patkai Hills, are home to eastern Himalayan broadleaf forests. Toward the northern border, with increasing elevation, comes a mixture of eastern and northeastern Himalayan subalpine conifer forests followed by the eastern Himalayan alpine shrub and meadows and ultimately rock and ice on the highest peaks.

Species of the family Tettigoniidae, known in American English as katydids and in British English as bush crickets, are very attractive in appearance. They are part of the suborder Ensifera and the only family in the superfamily Tettigonioidea. They are also known as long horned grasshoppers although they are more closely related to crickets than to grasshoppers. They are widely distributed in tropical and subtropical parts of the world (Heller 1995). Tettigoniidae is a widely distributed family that includes about 6000 species in 1070 genera (Otte 1997). Out of these

Abbreviations: BMNH - Natural History Museum, London, United Kingdom; LSUK - Linnean Society, United Kingdom, London; MZPW - Museum Ziemi PAN, Warsaw, Poland; MHNG - Museum d'histoire Naturelle in Geneva, Switzerland; MNHN - Museum National d'histoire Naturelle, Paris, France; NHMV - Naturhistorisches Museum Vienna; SMFD - Naturmuseum Senckenberg, Frankfurt am Main, Germany; ZMUM - Zoological Museum University of Moscow; ZSI - Zoological Survey of India, Kolkata, West Bengal, India. 
only 159 species of 72 genera are reported from India (Shishodia et al. 2010). The adults are small to large $(15-120 \mathrm{~mm})$ and poorly known from India.

Some important works on the taxonomy and distribution of Tettigoniidae of northeastern India include: Barman \& Srivastava (1976), Shishodia (2000), Shishodia \& Tandon (2000), Barman (2003), Shishodia et al. (2003, 2010), Kulkarni \& Shishodia (2005), Senthilkumar et al. (2006), and Senthilkumar (2010). The present paper deals with 10 species. The classification is after Rentz (1979).

\section{Material and Methods}

All the specimens were handpicked during night from the street lights and in the early morning from the vegetation. The collected specimens were killed by using ethyl acetate and preserved as dry specimens. The pinned specimens were subjected to taxonomic studies by using Olympus SZX10 microscope.

All the studied specimens are deposited at the Arunachal Pradesh Regional Centre, Zoological Survey of India, Itanagar (APRC/ZSI).

\section{Systematic account}

Order: Orthoptera

Suborder: Ensifera

Superfamily: Tettigonioidea

Family: Tettigoniidae

\section{Subfamily: Phaneropterinae}

Genus Khaoyaiana Ingrisch, 1990

1. Khaoyaiana nitens Ingrisch, 1990

Genus Trachyzulpha Dohrn, 1892

2. Trachyzulpha fruhstorferi Dohrn, 1892

Subfamily:_Pseudophyllinae

Genus Chloracris Pictet \& Saussure, 1892

3. Chloracris brullei, Pictet \& Saussure, 1892

Genus Pseudophyllus Serville, 1831

4. Pseudophyllus neriifolius (Lichtenstein, 1796)

Genus Onomarchus Stål, 1874

5. Onomarchus uninotatus (Serville, 1838)

Genus Phyllozelus Redtenbacher, 1892

6. Phyllozelus (Phyllozelus) siccus siccus (Walker, 1869)

Subfamily: Conocephalinae Genus Euconocephalus Karny, 1907
7. Euconocephalus indicus (Redtenbacher, 1891)

Genus Pyrgocorypha Stål, 1873

8. Pyrgocorypha subulata (Thunberg, 1815)

Subfamily: Mecopodinae

Genus Mecopoda Serville, 1831

9. Mecopoda elongata elongata (Linnaeus, 1758)

Subfamily: Listroscelidinae

Genus Hexacentrus Serville, 1831

10. Hexacentrus unicolor Serville, 1831

Subfamily: Phaneropterinae

Genus Khaoyaiana Ingrisch, 1990

1. Khaoyaiana nitens Ingrisch, 1990 (Image 1)

1990. Khaoyaiana nitens, Ingrisch, Senckenbergiana Biologica, 70(1-3): 107. Holotype, Male,

Type locality: Thailand; SMFD Frankfurt.

1994. Khaoyaiana nitens, Jin, Xingbao \& K. L. Xia, Jour. Orth. Res., 3: 22.

1998. Khaoyaiana nitens, Ingrisch \& Shishodia, Mitt. Schweiz. Ent. Gesellsch., 71(3-4): 365.

2000. Khaoyaiana nitens, Ingrisch \& Shishodia, Mitt. Münch. Ent. Ges., 90: 20.

2002. Khaoyaiana nitens, Ingrisch, Entomologica Basiliensia, 24: 127.

2004. Khaoyaiana nitens, Shishodia \& Barman, Zool. Surv. India, State Fauna Series, Fauna of Manipur, 10 (2): 141.

Material examined: One female, 15.xi.2006, Ganga Lake, Papumpare District, Arunachal Pradesh,

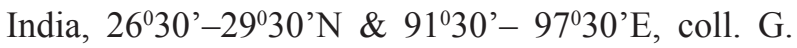
Srinivasan, Reg.No. IV/2299/APRC/ZSI.

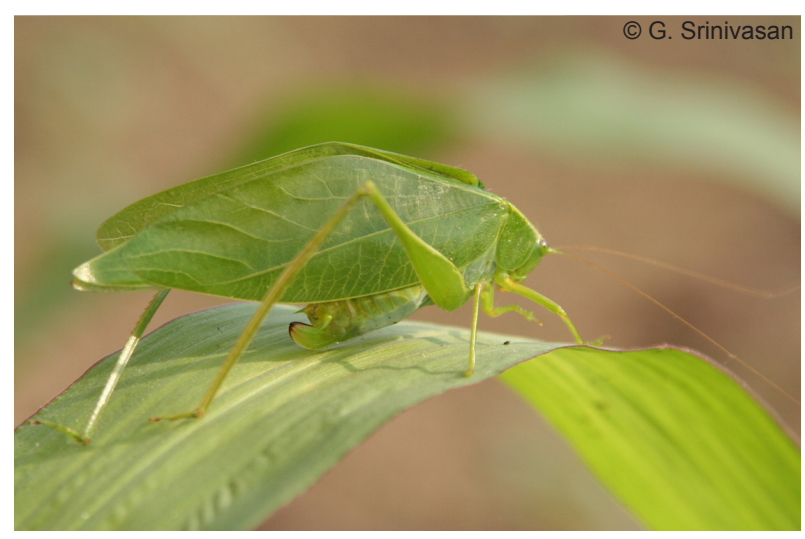

Image 1. Khaoyaiana nitens Ingrisch, 1990 
Diagnosis: Fastigium conical, apex blunt, furrowed dorsally; fastigium verticis slightly surpassing the rim of the antennal scrobae. Rounded eyes, little strongly accentuated. Antenna not surpassing the elytra. Disc of pronotum smooth, more or less straight in front, with hind end convex. Sulcus short before the middle. Pronotum higher than long, hind end almost straight, lower rim wide rounded off with coarse. Prosternum unarmed. The wing hyaline, protruding part chitinous and glossy green. Legs with the following number of spines on dorsal margins: profemur, mesofemur and postfemur smooth; protibia smooth. The mesotibia is smooth on dorso-external and with two spines on dorso-internal side. The posttibia with 30 minute, distinct, black tipped external and 28 minute, distinct, black tipped internal spines. Legs with the following number of spines on ventral margins: profemur and mesofemur smooth but the postfemur with four minute, distinct, black tipped external and seven minute, distinct, black tipped internal spines and with an apical spine; protibia with one external and two internal, mesotibia with four minute, distinct, black tipped external and four minute, distinct, black tipped internal, posttibia with five distantly placed minute, distinct, black tipped ventro-external and 11 minute, distinct, black tipped ventro-internal and with a pair of apical spines on each side. Post tibiae on sides compressed and spread out on all four sides. Supra anal plate long and triangular or tongue shaped; cerci long, lean gradually against the apex rejuvenated and acuminate and symmetrical. Ovipositor broad. Dorsal valvula somewhat shorter than the ventral valvula. On the dorsal part of the valvula are toothed, starting from middle part to apex at the ventral side of the valvula. Subgenital plate long and wide basolaterally; basal triangular indented, lateral far raised and apical supported. The tibial tympana open on both the sides.

Colouration: Green, glossy, ovipositor dark brown.

Measurements (in mm): Total Length 55; Body 22; Fastigium 3.5; Pronotum 9; Tegmen 43; Profemur 10; Mesofemur 7; Postfemur 28; Protibia 9; Mesotibia 6; Posttibia 30; Ovipositor 5.

Distribution: India: Arunachal Pradesh, Manipur, Meghalaya and Mizoram; Bhutan; Central Thailand; China.

Remarks: New record for Arunachal Pradesh.
Genus Trachyzulpha Dohrn, 1892

2. Trachyzulpha fruhstorferi Dohrn, 1892 (Image 2)

1892. Trachyzulpha fruhstorferi, Dohrn, Stett. Entomol. Z., 53: 68. Holotype, female, Type locality: Asia-Tropical, Malaysia, Jawa; (MZPW) Warsaw.

1906. Trachyzulpha fruhstorferi, Kirby, W.F. A synonymic catalogue of Orthoptera (Orthoptera, saltatoria, Locustidae Vel Acrididae) 2: 408.

1926. Trachyzulpha fruhstorferi, Karny, Jour. Fed. Malay States mus. 13(2-3): 81.

1936. Trachyzulpha fruhstorferi, Heller, K.M. \& K. Günther, Tijdschr. v. Entomologie 79: 74.

1962. Trachyzulpha fruhstorferi, Bei-Bienko, Trudy Zool. Inst. Akad. Nauk. SSSR, Leningrad. 30: 124.

1994. Trachyzulpha fruhstorferi, Jin, Xinghao \& Hsia, Jour. Orth. Res. 3: 24.

Material examined: One male, 03.vi.2008, DFO Quarters, Jengging, East Siang District, Arunachal Pradesh, India, 28034'14.0”N \& 95003'37.6”'E, coll. G. Srinivasan, Reg.No. IV/2300/APRC/ZSI.

Diagnosis: Fastigium sulcated, laterally compressed and conically produced with blunt apex, fastigium verticis distinctly surpassing the rim of the antennal scrobae. Eyes are protruded. The anterior margin of pronotum concave and posterior margin convex. The pronotal margins expands like armour with the lateral carinae denticulated. There is a clearly marked black colour "W-shaped" band attached with an inverted "V-shaped" structure on the dorsal side of the pronotal constriction. The posterior margin of the pronotum appears black because it is dotted with black. The lower half of the lateral sides of the pronotum is pale green

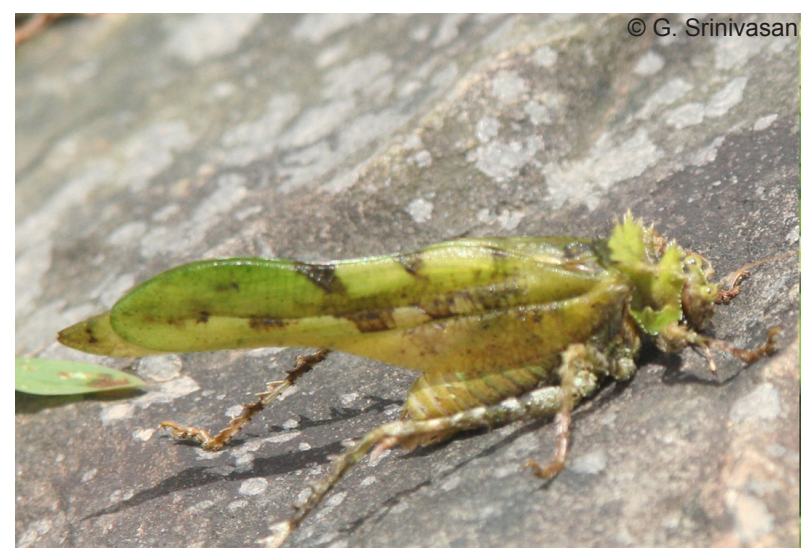

Image 2. Trachyzulpha fruhstorferi Dohrn, 1892 
and the upper half is black. The prosternum unarmed. A pale coloured band runs on the ventral side of the abdomen. The radius sector two of the tegmina arises before the middle. The hind femur with 10 spines on its external margin of the ventral side. The basal three are small and the remaining spines are gradually increasing in their size with the space in between them. No spines on the inner margin. A long apical spine present on the external side and a short spine on the internal side of the hind femur. The dorsal side of the hind femur is smooth. The dorsal side of hind tibia bearing six sickle-shaped spines on its external margin and 10 on its internal margin. The ventral side of the hind tibia has 11 normal shaped spines. The base of the spines is dark brown and the tips are red. The fore tibia has three spines on the external margin, eight spines on the middle and 10 on the internal margin of the dorsal side. The subgenital plate broadest at the base and then narrowed posteriorly. The lobes of the united styli curved inward with a blunt end at the apex. The circus gradually narrowed, covered with spinules, bristles and curved at apex. The tibial tympana open on both the sides.

Colouration: Body is green. The tegmina are green with five white-centered discontinuous transverse black bands. The femur and tibia of the three pair of legs are transversed with black and white coloured bands.

Measurements (in mm): Total Length 58; Body 23; Fastigium 2; Pronotum 8; Tegmen 45; Profemur 9; Mesofemur; Postfemur 20; Protibia 7; Mesotibia; Posttibia 22.

Distribution: India: Arunachal Pradesh; Indonesia: Java; Malaysia; Thailand.

Remarks: New record for India.

\section{Subfamily: Pseudophyllinae}

Genus Chloracris Pictet \& Saussure, 1892.

3. Chloracris brullei Pictet \& Saussure, 1892 (Image 3)

1892. Chloracris brullei, Pictet \& Saussure, Iconographie des quelques sauterelles vertes, p. 22. Syntype, Male \& female, Type locality: Asia-Tropical, Malaysia, Java, (MHNG) Geneva Museum.

1895. Pseudophyllus brullei, Brunner Von Wattenwyl, Verh. Der. Zoologish Botanischen. Gesellsch. Wien, 45: 37.

1906. Chloracris brullei, Kirby, A synonymic catalogue of orthoptera, 2: 294.

1938. Chloracris brullei, De Jong, Zoologische Mededeelingen XXI: 9.

1945. Chloracris brullei, De Jong, C. Zool. Mededelingen. (Leiden) 25: 5.

1954. Chloracris brullei, Beier, Revision der Pseudophyllinen 66.

1995. Chloracris brullei Heller, K.G. Jour. Zool., London, 237: 480.

Material examined: One female, 15.xi.2006, Ganga Lake, Papumpare District, Itanagar, Arunachal

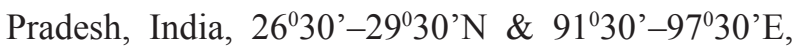
coll. G. Srinivasan, Reg.No. IV/2301/APRC/ZSI.

Diagnosis: Fastigium, shortened apically, verticis conical, apex blunt, dorsally furrowed, slightly surpassing the rim of the crowded antennal scrobae. The dorsal surface of pronotum smooth, bears two distinct sutures. The lower margin of the lateral pronotum is undulated. Prosternum unarmed. The chief specific characters of the species are those of the form of the tegmina and their venation. Absence of ocelli on the tegmen. This species should be identified after the spines on their hind legs. The dorsal side of the hind femora is smooth. The number of spines on the ventro-external margin of the hind femora is 13 and as a rule these spines are a little longer than the spines of the internal margin. The number of smaller spines on the ventro-internal margin of the hind femora is 10 . There are four spines on the dorso-internal margin of the hind tibia. The dorso-external margin of the hind tibia is smooth. The number of spines on the ventroexternal margin of the hind tibia is eight. The number of spines on the ventro-internal margin of the hind tibia

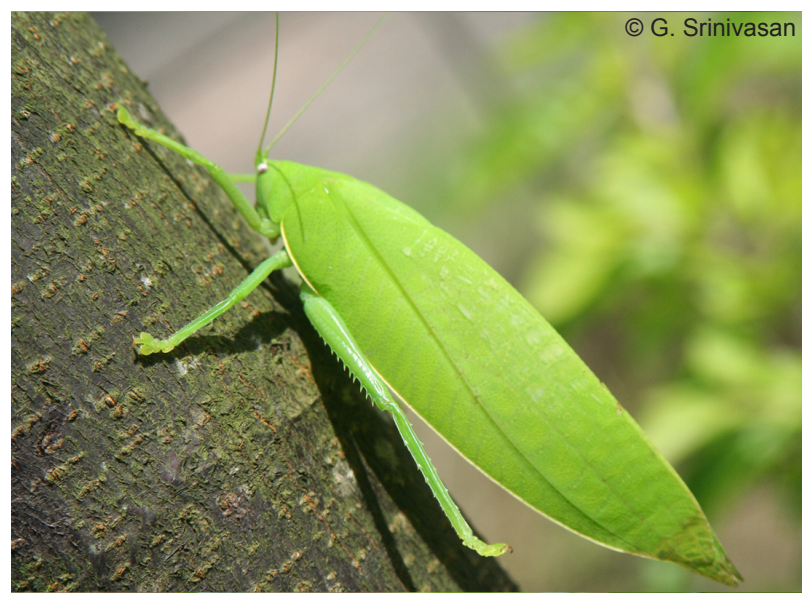

Image 3. Chloracris brullei, Pictet \& Saussure, 1892 
is seven and as a rule these spines are a little smaller. The number of spines on the ventro-external margin of the mid leg femur is seven whereas five long spines on the internal margin and they are in equal distance. There are five very short spines on the ventro-internal margin of the mid leg femur. There are only two spines on the dorsal side of the mid leg tibia. There are eight spines on the ventro-external margin and six on the ventro-internal margin of the mid leg tibia. The dorsal side of the fore femur smooth. There are five spines on the ventro-internal margin of the hind femur and four spines on the ventro-external margin. The ventro-internal margin of the fore tibia has five spines and six on the ventro-external margin. Tibial tympana closed on both the sides.

Colouration: The general colour of the specimen is green.

Measurements (in mm): Total length 116; Body 55; Fastigium 4; Pronotum 12; Tegmen 97; Profemur 14; Mesofemur 15; Postfemur 28; Protibia 11; Mesotibia 14; Posttibia 26; Ovipositor 27.

Distribution: India: Arunachal Pradesh; Indonesia: Borneo, Sumatra, Java; China; Malaysia.

Remarks: New record for India.

Genus Pseudophyllus Serville, 1831.

\section{Pseudophyllus neriifolius (Lichtenstein, 1796)}

\section{(Image 4)}

1796. Locusta neriifolia, Lichtenstein, Cat. Mus. Zool. Hamburg 3: 82. Syntype, Female, Type locality: Asia-Tropical, Malaysia, Jawa, (ZMUM). Hamburg.

1813. Gryllus Tettigonia neriifolius, Stål, Representation exactement colorée d'après nature des spectres ou phasmes, des mantes, des sauterelles, des grillons, des criquets et des blattes: 11.

1831. Pseudophyllus neriifolius, Serville, Ann. Sci. nat., 22(86): 143.

1835. Pseudophyllus neriifolius, Brullé, In Audouin \& Brullé. Histoire naturelle des insectes, 9[1](5): 137.

1838. Pseudophyllus neriifolius, Serville, Histoire naturelle des insectes, Orthoptères, 466.

1842.Locusta (Pseudophyllus) granigera, De Haan, In Temminck. Verhandelingen over de natuurlijke geschiedenis der Nederlandsche overzeesche bezittingen Zoologie: 203.

1862. Pseudophyllus neriifolius, Brunner von Wattenwyl, Abh. Zool.-bot. Ges. Wien, 12: 93.
1892. Cleandrus neriifolius, Pictet \& Saussure, Iconographie des quelques sauterelles vertes: 12 .

1895. Chloracris neriifolius, Brunner Von Wattenwyl, Verh. Der Zoologisch-botanischen Gesellsch. Wien 45: 36.

1906. Cleandrus neriifolius, Kirby, A Synonymic Catalogue of Orthoptera (Orthoptera Saltatoria, Locustidae vel Acridiidae) 2: 295.

1919. Cleandrus neriifolius, Dammerman, Landbouwdierkunde: 100.

1924. Cleandrus neriifolius, Karny, Treubia 5(13): 173 .

1927. Pseudophyllus neriifolius, Caudell, Proc. U. S. Nation. Mus.71 (3), p. 32.

1927. Cleandrus neriifolius, Karny, Ark. Zool., 19A(12): 7.

1927. Cleandrus neriifolius, Ebner, Misc. Zool. Sumatrana, 20: 6.

1938. Pseudophyllus neriifolius, De Jong, Zoologische Mededeelingen XXI: 14.

1939. Pseudophyllus neriifolius, De Jong, C. Zool. Mededelingen (Leiden) 21: 14.

1945. Pseudophyllus neriifolius, De Jong, C. Zool. Mededelingen (Leiden) 25: 6.

1960. Pseudophyllus neriifolius, De Jong, C. Zoologische Verhandelingen 45: 7.

1963.Pseudophyllusneriifolius, Beier, Orthopterum catalogus 5: 15.

Material examined: One male, 14.vi.2005, Papumpare District, Arunachal Pradesh, India; ZSI Quarters Main gate, Itanagar, $27^{0} 5^{\prime}-35^{0} 72^{\prime} \mathrm{N}$ \& 93037'-30² ${ }^{\circ}$ E, coll. G. Srinivasan, Reg.No. IV/2302/ APRC/ZSI.

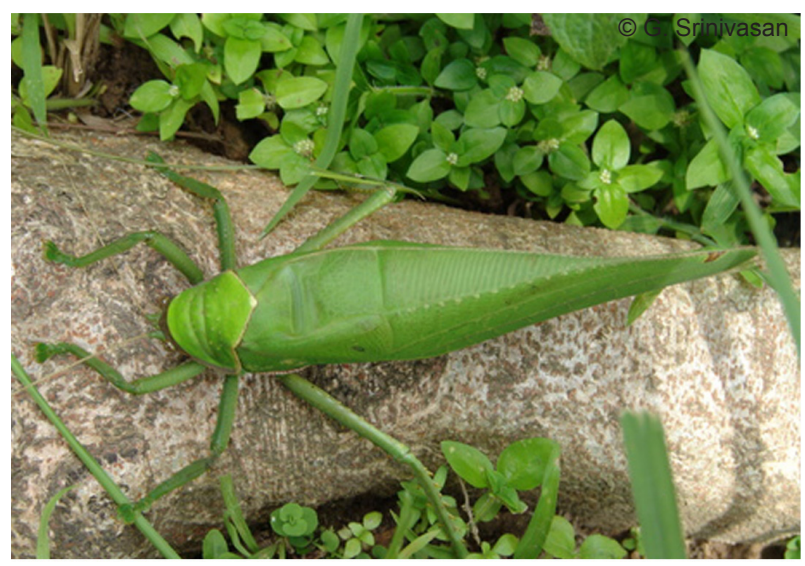

Image 4. Pseudophyllus neriifolius (Lichtenstein,1796) 
Diagnosis: Fastigium verticis conical, dorsally furrowed, extends well beyond the rim of antennal scrobae. The species is easily known by the rather inflated general shape, the granulated pronotum with an angulated hind border, granulated margins of pronotum, the unicolourous vertex and the ocellate elytra. Prosternum unarmed. Meso and metasternum broader than long; lobes angulated; metasternum narrowing posteriorly. In the males the anterior branch of medial vein is bent anterior near the base and the ocelliform markings are found between the two branches of medial vein just behind this curved part of the anterior branch. The chief specific characters of the species are those of the form of the tegmina and their venation. This species should be identified after the spines on their hind legs. There are 13 spines on the dorsal side of the hind femora. The number of spines on the ventro-external margin of the hind femora is 13 and as a rule these spines are a little longer. The number of spines on the ventro-internal margin of the hind femora is 12 . There are six spines on the dorsal side of the hind tibia among them the $1^{\text {st }}$ one is small and the distance between the $1^{\text {st }}$ and $2^{\text {nd }}$ spine is very less when compared to the distance between the rest of the spines i.e. from 2-6. The number of spines on the ventro-external margin of the hind tibia is nine. The number of spines on the ventro-internal margin of the hind tibia is nine and as a rule these spines are a little smaller. The number of spines on the ventro-external margin of the fore femur is seven whereas four long spines on the internal margin and they are in equal distance. There are eight small spines on the ventrointernal margin of the fore tibia and the basal three are less in interspine distance when compare to the interspine distance of $4^{\text {th }}-8^{\text {th }}$ spines. There are seven spines on the ventro-external margin of the fore tibia. Tibial tympana closed on both the sides.

Colouration: The general colour of the specimen is green.

Measurements (in mm): Total length 123; Body 60; Fastigium 4; Pronotum 19; Tegmen 103; Profemur 15; Mesofemur 16; Postfemur 30; Protibia 15; Mesotibia 14; Posttibia 28.

Distribution: India: Arunachal Pradesh; Indonesia: Java and Sumatra.

Remarks: New record for India.
Genus Onomarchus Stål, 1874

\section{Onomarchus uninotatus (Serville, 1838)}

(Image 5)

1838. Pseudophyllus uninotatus, Serville, Histoire naturelle des insectes. Orthoptères, p. 468. Holotype, Female, Type locality: MHNG, Geneva Museum.

1842. Locusta (Pseudophyllus) leuconota var. b. leuconota, uninotata, De Haan, In Temminck. Verhandelingen over de natuurlijke geschiedenis der Nederlandsche overzeesche bezittingen Zoologie: (nec leuconotus Serv.), p. 204, pl.20, figs. 9 and 10.

1862. Pseudophyllus uninotatus, Brunner von Wattenwyl, Abh. Zool.-bot. Ges. Wien 12: 93.

1906. Cleandrus uninotatus, Kirby, A Synonymic Catalogue of Orthoptera (Orthoptera Saltatoria, Locustidae vel Acridiidae) 2: 295.

1920. Pseudophyllus uninotatus Karny, Zool. Mededelingen (Leiden) 5(4): 208.

1924. Cleandrus neriifolius uninotatus, Karny, Treubia 5(1-3): 174.

1938. Onomarchus uninotatus, De Jong, Zoologische Mededeelingen, XXI: 26.

1939. Pseudophyllus uninotatus, De Jong, Zool. Mededelingen (Leiden) 21: 26.

1945. Onomarchus uninotatus, De Jong, Zool. Mededelingen (Leiden) 25: 6.

1954. Onomarchus uninotatus, Beier, Revision der Pseudophyllinen 60, 61.

1960. Onomarchus uninotatus, De Jong, C. Zoologische Verhandelingen 45: 8.

1962. Onomarchus uninotatus, Beier, Tierreich,73: 45.

1965. Onomarchus uninotatus, Weidner, Ent. Mitt.

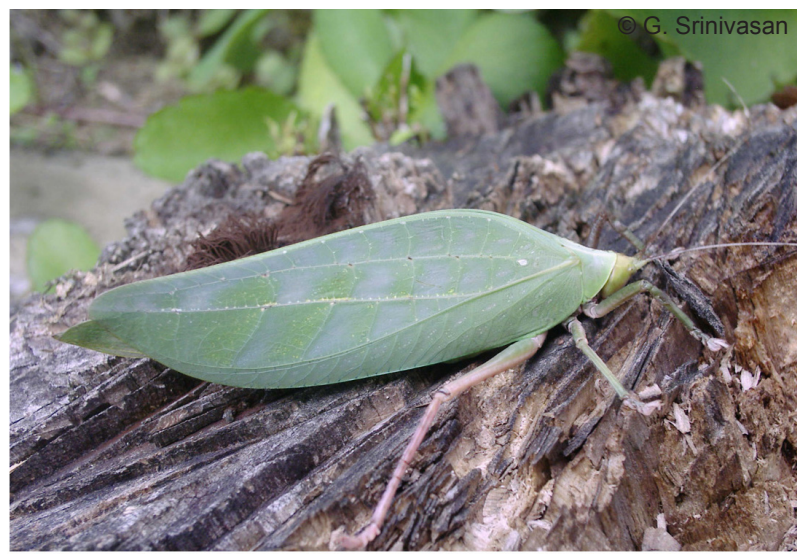

Image 5. Onomarchus uninotatus (Serville, 1838) 
Zool. Museum Hamburg 3(53): 88.

1990. Onomarchus uninotatus, Ingrisch, Senckenbergiana Biologica, 70(1-3): 133.

1994. Onomarchus uninotatus, Jin, Xingbao \& K.-

L. Xia, Jour. Orth. Res. 3: 25.

1995. Onomarchus uninotatus, Heller, K.-G., Jour. Zool., London, 237: 479.

Material examined: Two females, 08.x.2004, Papumpare District, Arunachal Pradesh, India; ZSI Quarters main gate, Itanagar, $27^{0} 5^{\prime}-35^{\circ} 72^{\prime} \mathrm{N} \&$ 93 $3^{\circ} 37^{\prime}-$ $30^{\circ} 72^{\prime}$ E, coll. G. Srinivasan, Reg.No. IV/2304/APRC/ ZSI \& IV/2305/APRC/ZSI. 1 Female, 09.xi.2005, East Kameng District, Arunachal Pradesh, India; Seijosa I. B, Pakke Tiger Reserve, $92^{0} 35^{\prime}-93^{\circ} 10^{\prime} \mathrm{N} \& 26^{0} 55^{\prime}-$ $27^{0} 15^{\prime}$ E, coll. G. Srinivasan, Reg.No. IV/2306/APRC/ ZSI.

Diagnosis: Fastigium verticis triangular, apex obtuse, dorsally furrowed, slightly surpassing rim of antennal scrobae. No minute pits are found in the area below the eyes. Pronotum smooth with very few isolated tubercles; with one transverse furrow in the anterior half of the disc; anterior margin broadly rounded, posterior margin angular; paranota acutetriangular in general outline but ventral margin truncate, latero-anterior margin faintly convex with very faint sinuosities in ventral half, latero-posterior margin concave. Tegmen broad, semitransparent, oval and of a pale green but rather narrow for the genus; subcosta running distant from radius to behind branching of radius sector, and after a short approach deviating again; media with a sinuate curvature in basal area. Prosternum unarmed. Meso and metasternum transverse, mesosternum with a minute tubercle at anterior-lateral angle, metasternum narrowing posteriorly. The meso and metasternum together are about as long as broad. Legs with the following number of spines on ventral margins: profemur six indistinct external and seven indistinct internal, mesofemur six minute external and seven internal, postfemur five indistinct, one minute and five large external, 13 minute internal; protibia six minute external and seven minute internal, mesotibia five minute external and five indistinct internal, posttibia nine small external and seven minute internal. All tibiae with two ventroapical spurs, without dorsal spurs. Posttibia on dorsal margins with six minute external and seven large and broad internal spines. The hind tibiae bear a row of strong broadly based thorns on its dorsal margins, which are situated at equal distances. Tibial tympana closed on both the sides.

Colouration: The general colour is green. In the females the tegmina has a distinct white spot near the base, situated between the radial and the medial vein. The pronotum is green. The head is yellowishgreen, the forehead is dark green, broadly bordered with white along the genae. The clypeus, labrum and the mandibulate are of a whitish-green. The general colour of the legs is of a greenish-grey shade, but the middle femora and tibiae are white below.

Measurements (in mm): Total length 90; Body 40; Fastigium 4; Pronotum 8; Tegmen 70; Profemur 9; Mesofemur 10; Postfemur 20; Protibia 9; Mesotibia 10; Posttibia 20; Ovipositor 26.

Distribution: India: Arunachal Pradesh; Australia; Indoensia: Java and Sumatra; Malaysia; Ambonia; Banka; Batoe Islands.

Remarks: New record for India.

Genus Phyllozelus Redtenbacher, 1892

Subgenus Phyllozelus (Redtenbacher, 1892)

6. Phyllozelus (Phyllozelus) siccus siccus (Walker, 1869). (Image 6)

1869. Pseudophyllus siccus, Walker, Cat. Derm. Salt. Brit. Mus., 2: 403. Holotype, female, Type locality: Asia-Tropical, Indian Subcontinent, India (Chennai), (BMNH). London.

1869. Pseudophyllus signatus, Walker, Cat. Derm. Salt. Brit. Mus., 2: 407.

1893. Phyllozelus infumatus, Brunner Von Wattenwyl, Ann. Mus. Civ. Stor. Nat. Giacomo Doria Genova, Ser 2, 13(33): 174.

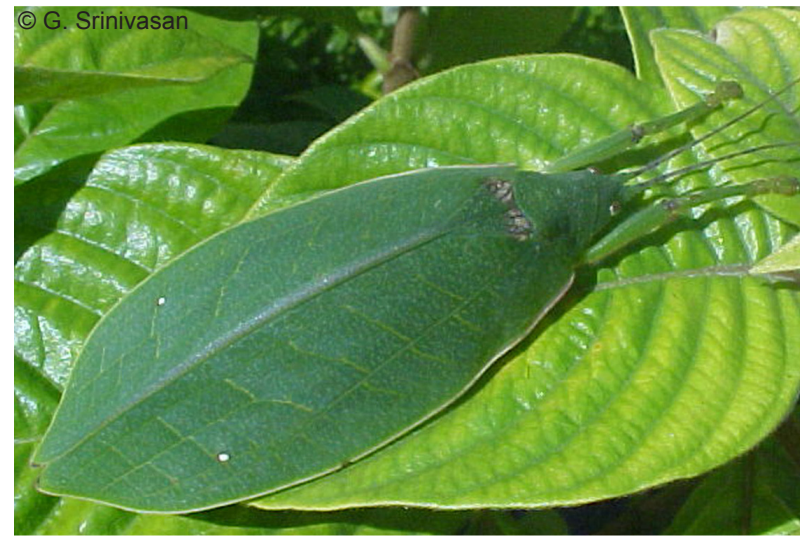

Image 6. Phyllozelus (Phyllozelus) siccus siccus (Walker, 1869) 
1962. Phyllozelus siccus, Beier, Das Tierreich, 73: 102.

2003. Phyllozelus siccus, Barman, Zool. Surv. India, State Fauna series: Fauna of Sikkim, 9(2): 200.

Material examined: One female, 15.xi.2006, Papumpare District, Arunachal Pradesh, India; Ganga

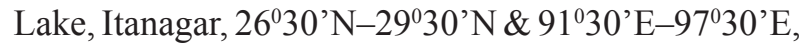
coll. G. Srinivasan, Reg.No. IV/ 2307/APRC/ZSI.

Diagnosis: Robust species. Fastigium verticis narrow conical, dorsally furrowed, apex blunt, not surpassing the rim of antennal scrobae. Pronotum not roof-shaped, carinated and granulated with a transverse sulcus distinct on the disc and paranota, obsolete on lateral angles; margins of pronotum not granulated; anterior margin sinuate, convex in middle, posterior margin broadly rounded but convex in the middle; paranota about as high as long, anterior and posterior angle almost rectangular. Prosternum armed; meso and metasternum strongly transverse, all of them as long as wide, lobes blunt; Tegmen broad and leaf like, surpassing hind knees; radius sector branching slightly before the middle of tegmen length, forked. The cubitus of Tegmina pedunculate basally. This species is easily known by the curious rugose erosion path in the anal area of the tegmina and by the peculiar venal pattern. The subcostal and radial veins diverge about the same place, where the branch of the radial vein finds its origin namely a little before the middle of the tegmina. Hind wing caudate. Anterior femora compressed. Knee lobes of all legs bispinose. Legs with the following number of spines on ventral margins: profemur no external and three indistinct internal, mesofemur five minute external and seven internal, postfemur one indistinct, 11 large, broad based external and 11 large internal, mesotibia five minute indistinct external and seven minute internal, posttibia nine small external and seven minute internal. All tibiae with two ventro-apical spurs, without dorsal apical spurs. No spines on femur and tibia on the dorsal margins. Tibial tympana closed on both the sides.

Colouration: The species when at rest on leaves camouflage like a leaf and leafy green in colour. The dorsal sides of meso and postfemur are blue in colour with sky-blue dots in between and the ventral side is light yellow. The protibia and femur are green in colour. The meso tibia is green. The tip of the ovipositor is dark brown to black.

Measurements (in mm): Total length 55; Body 35;
Fastigium 4; Pronotum 9; Tegmen 60; Profemur 10; Mesofemur 10; Postfemur 20; Protibia 9; Mesotibia 10; Posttibia 19; Ovipositor 15.

Distribution: India: Assam, Arunachal Pradesh, Sikkim and Tamil Nadu; Indonesia: Sumatra.

Remarks: New record for Arunachal Pradesh.

\section{Subfamily: Conocephalinae}

Genus Euconocephalus Karny, 1907

7. Euconocephalus indicus (Redtenbacher, 1891)

(Image 7)

1891. Conocephalus indicus, Redtenbacher, Verh. Zool.-bot. Ges. Wien, 41: 408, Lectotype, Male, Type locality: Asia-Tropical, Indian Subcontinent, India, Himalaya. (NHMV).

1979. Euconocephalus indicus, Winston J. Bailey, Aust. J. Zool., 27: 1032.

1992. Euconocephalus indicus, Hebard, Proc. Acad. Nat. Sci. Philad., 74: 238.

1998. Euconocephalus indicus, Ingrisch \& Shishodia, Mitt. Schweiz. Ent. Ges., 71: 370.

2000. Euconocephalus indicus, Ingrisch \& Shishodia, Mitt. Munch. Ent. Ges., 90: 32.

2004. Euconocephalus indicus, Shishodia \& Barman, Zool. Surv. India, Fauna of Manipur, State Fauna series, 10(2): 143.

Material examined: One female, 10.x.2005, Papumpare District, Arunachal Pradesh, India; Itanagar Zoological Park, 26030'-29030'N \& 91030'E-97030'E, coll. G. Srinivasan, Reg.No. IV/2308/APRC/ZSI.

Diagnosis: Fastigium short, as long as broad, surpassing the antennal sockets; apex of the fastigial vertex blunt, rounded; ventral notch clearly open, ventral tubercle small. Antennae not annulated.

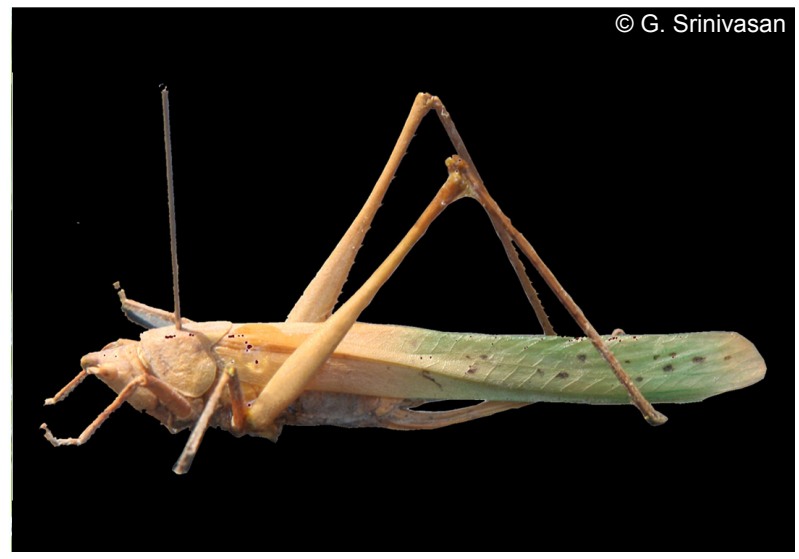

Image 7. Euconocephalus indicus (Redtenbacher, 1891) 
Pronotum converging towards the posterior margin from the dorsal aspect, side keels deep and not markedly elongate. Prosternum armed with a pair of spines. Anterior lobes of meso and metasternum rounded and the posterior lobes are angulated. Forewings long, surpassing hind knees with the tip rounded. Radius sector two arise beyond the middle of the wing. Cubito-anal area of forewing not distinctly broadened or rounded. All legs are long and slender. Post femora armed both externally and internally on the ventral aspect. Legs with the following number of spines on ventral margins: profemur no external and two indistinct internal, mesofemur four minute external and no internal, postfemur seven minute external and 14 minute internal, protibia with six external and six internal, mesotibia with six external and six internal, posttibia 25 small external and 25 small internal. All tibiae with two ventro-apical spurs and post tibia with an apical spur on dorsal its margin. Postfemur smooth. Posttibia with the following number of spines on dorsal margins: 28 small external and 25 small internal. Ovipositor longer than the body and straight. The tibial tympana closed on both the sides.

Colouration: General colouration green. Tip of the spines in both ventral margins of the post femur are dark brown in colour. Tip of the spines in both ventral margins of the protibia, mesotibia and posttibia are dark brown in colour. Mandibles and hind femur are pale brown. There are 12-15 distinct black spots on the posterior half of the tegmen.

Measurements (in mm): Total Length 62; Body 26; Fastigium 4; Pronotum 8; Tegmen 50; Profemur 8; Mesofemur 10; Postfemur 28; Protibia 7; Mesotibia 9; Posttibia 26; Ovipositor 30.

Distribution: India: Arunachal Pradesh, Manipur, Meghalaya, Mizoram and Odisha; Australia; China; Myanmar; Thailand; Malaysia: Penang, Peak Dovens; Indonesia: Java, Borneo and Sumatra.

Remarks: New record to Arunachal Pradesh.

Genus Pyrgocorypha Stål, 1873

8. Pyrgocorypha subulata (Thunberg, 1815) (Image 8)

1815. Conocephalus subulatus, Thunberg, Mem. Acad. Imp. Sci. St. Petersburg 5: 271.Syntype, Type locality: Oriental region, (BMNH) London.

1874. Pyrgocorypha subulata, Stal, Recencio orthopterum. Revue Critique des orthopteres decrits par Linne, De Geer et. Thunberg, 2 Locustina: 107.

1891. Pyrgocorypha subulata, Redtenbacher, Verh. der Zoologisch-Botanischen Gesellsch. Wien 41: 372, 374.

1893. Pyrgocorypha subulata, Brunner Von Wattenwyl, Ann. Mus.Civ.Stor. Nat. Genova. 213: (33) 179.

1906. Pyrgocorypha subulata, Kirby, A synonymic catalogue of orthoptera (Orthoptera, saltatoria, Locustidae Vel Acrididae) 2: 239.

1912. Pyrgocorypha subulata, Karny, Genera Insectorum. 139: 26.

1926. Pyrgocorypha subulata, Karny, Treubia 9(13): 240 .

1955. Pyrgocorypha subulata, Bei-Bienko, Zoologischeskii. Zhurnal 34: 1263.

1957. Pyrgocorypha subulata, Bei-Bienko, Entomologicsheskoe obozrenie 36: 413.

1990. Pyrgocorypha subulata, Ingrisch, Senckenbergiana Biologica 70(1-3): 116.

1994. Pyrgocorypha subulata, Jin, Xingbao \& Hsia, Jour. Orth. Res. 3: 15-41.

2002. Pyrgocorypha subulata, Ingrisch, Entomological Basiliensia 24: 113.

2008. Pyrgocorypha subulata, Buzzetti \& Devriese, Bull.Mus. Civ. St. nat. Verona. 32: 162.

Material examined: One female, 15.vi.2005, Papumpare District, Arunachal Pradesh, India; Itanagar Zoological Park, 26030'N-29030'N \& 91030’E-97030'E, coll. G. Srinivasan, Reg.No. IV/2309/APRC/ZSI.

Diagnosis: Fastigium long and conical, narrowing towards the tip; apex of the fastigial vertex acute,

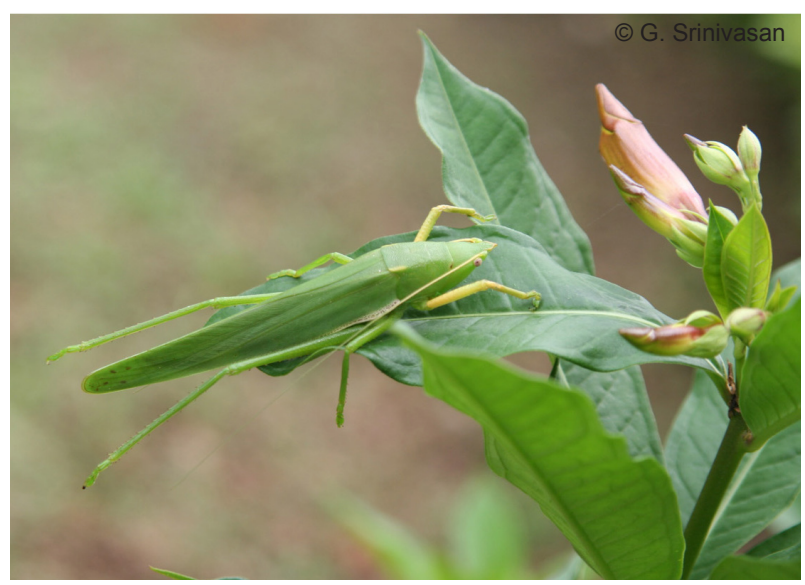

Image 8. Pyrgocorypha subulata (Thunberg, 1815) 
with the ventral notch clearly open, ventral tubercle small. Pronotum diverging towards the posterior margin from the dorsal aspect, lateral keels shallow and not markedly elongate. Prosternum armed with a pair of spines. Forewings long with the tip rounded. Cubito-anal area of forewing not distinctly broadened or rounded. The pro femur has a single spine on its external margin and three spines on the internal margin on the ventral side. Hind femora armed both internally and externally on the ventral side. There are 13 spines on the external margin whereas seven spines on the internal margin. The distance between the spines on the external margin is lesser than the internal margin. There are seven spines on the internal margin of the pro tibia on the ventral aspect; the distance between the first four and the last two are somewhat lesser than the distance between the $5^{\text {th }}$ and $6^{\text {th }}$. The protibia has five spines on the internal margin and four spines on the external margin on the ventral side. The profemur and the protibia are smooth on the dorsal side. The tibial tympana closed on both the sides.

Colouration: Body green. A prominent white coloured band bordered with many black dots runs along the lower margin of the cubito-anal area of the tegmina. The fore legs are yellow.

Measurements (in mm): Total Length 71; Body 35; Fastigium 5.5; Pronotum 10; Tegmen 53; Profemur 9; Mesofemur 11; Postfemur 23; Protibia 7; Mesotibia 9; Posttibia 21; Ovipositor 28.

Distribution: India: Arunachal Pradesh; Bhutan: Bhamo; China; Malaysia; Myanmar; Indonesia: Java.

Remarks: New record for India.

\section{Subfamily: Mecopodinae}

Genus Mecopoda Serville, 1831

\section{Mecopoda elongata elongata (Linnaeus, 1758)} (Image 9)

1758. Gryllus (Tettigonia) elongatus, Linnaeus, Systema Naturae per Regna tria naturae (10 ${ }^{\text {th }}$ ed.) 1: 429. Syntype, Female, Type locality: Asia-Tropical, Indian subcontinent, India, (LSUK) London Linnean Society.

1763. Gryllus javanus, Johannson, In Linnaeus, Amoenitates Academicae seu dissertations variae Physicae Medicae, Botanicae anthehac seorsum editae ( $2^{\text {nd }}$ ed.) 6: 398.

1767. Gryllus (Tettigonia) elongatus, Linnaeus, Systema Naturae per Regna tria naturae (12th ed.) 1, pt. 2: 696 .

1813. Gryllus (Tettigonia) ferruginea, Stoll, Spectres on Phasues des Mantes, des Sauterelles, 2: 9.

1813. Gryllus (Tettigonia) rufa, Stoll, Spectres on Phasues des Mantes, des Sauterelles, 2: 13.

1815. Locusta scalaris, Thunberg, Mem. Acad. Sci. St. Petersb., 5: 282.

1831. Mecopoda maculata, Serville, Ann. Sci. nat. (Zool.), Paris, 22: 155.

1835. Mecopoda virens, Brulle, In Audauin \& Brulle, Histoire naturelle des Insects, 9(1) (5): 140.

1835. Mecopoda virens, Brulle, Histoire naturelle des Insects, Paris, 9: 140.

1842. Locusta (Mecopoda) javana, Haan, Gesch. Ned. Overszee. Bezitt, 2: 187.

1869. Decticus tenebrosus, Walker, Cat. Derm. Salt. Brit. Mus.,: 262.

1869. Lucera bicoloripes, Walker, Cat. Derm. Salt. Brit. Mus.,: 265.

1906. Mecopoda elongata, Kirby, Syn. Cat. Orthopt., 2:364

1922. Mecopoda elongata, Hebard, Proc. Acad. Nat. Sci. Philad., 74: 182.

1924. Mecopoda elongata servillei, Karny, Meconeminen Ttreubia, 5: 159.

1976. Mecopoda elongata, Barman \& Srivastava, Newsl. Zool. Surv. India, 2(3): 93.

1993. Mecopoda elongata, Barman, Zool. Surv. India, State Fauna series, Fauna of West Bengal, 3 (4): 363.

1995. Mecopoda elongata, Barman, Zool. Surv. India, State Fauna series, Fauna of Meghalaya 4(3): 288.

2000. Mecopoda elongata, Ingrisch \& Shishodia, Mitt. Munch. Ent. Ges., 90: 21.

2000. Mecopoda elongata, Shishodia, Rec. Zool. Surv. India, 98(3): 14.

2000. Mecopoda elongata, Barman, Zool. Surv. India, State Fauna series, Fauna of Tripura, 7(2): 265.

2001. Mecopoda elongata, Shishodia \& Kulkarni, Zool. Surv. India, Fauna of Conservation Area Series, Fauna of Nilgiri Biosphere Reserve, 11: 62.

2002. Mecopoda elongata, Ingrisch, Entomologica Basiliensia, 24: 128.

2003. Mecopoda elongata, Barman, Zool. Surv. India, State Fauna series, Fauna of Sikkim, 9(2): 195. 
2004. Mecopoda elongata, Shishodia \& Barman, Zool. Surv. India, Fauna of Manipur, State Fauna series, 10(2): 142.

2005. Mecopoda elongata, Kulkarni \& Shishodia, Zool. Surv. India, Conservation Area Series, Fauna of Melghat Tiger Reserve, 24: 325.

2006. Mecopoda elongata, Shishodia, Zool. Surv. India, State Fauna series, Fauna of Nagaland, 12: 90.

2007. Mecopoda elongata, Chandra et al., Zoos' Print Journal, 22(5): 2684.

2009. Mecopoda elongata, Gupta \& Shishodia, Zool. Surv. India, Conservation Area Series: Fauna of Pachmarhi Biosphere Reserve, 39: 62.

Material examined: One female, 03.x.2004, Papumpare District, Arunachal Pradesh, India; ZSI Quarters main gate, Itanagar, $27^{0} 5^{\prime}-35^{0} 72^{\prime} \mathrm{N} \& 93^{0} 37^{\prime}-$ $30^{\circ} 72^{\prime}$ E, coll. G. Srinivasan, Reg.No. IV/2310/APRC/ ZSI. One female, 05.x.2004, Papumpare District, Arunachal Pradesh, India; ZSI Quarters main gate, Itanagar, coll. G. Srinivasan, Reg.No. IV/2311/APRC/ ZSI. One female, 10.x.2005, Papumpare District, Arunachal Pradesh, India; Itanagar Zoological Park, Itanagar, $26^{0} 30^{\prime}-29^{0} 30^{\prime} \mathrm{N} \& 9^{0} 30^{\prime}-97^{0} 30^{\prime} \mathrm{E}$, coll. G. Srinivasan, Reg.No. IV/2312/APRC/ZSI. One female, 09.xi.2005, East Kameng District, Arunachal Pradesh, India; Khari I.B, Seijosa, Pakke Tiger Reserve $92^{\circ} 35^{\prime}$ $93^{\circ} 10^{\prime} \mathrm{N} \& 26^{\circ} 55^{\prime}-27^{\circ} 15^{\prime} \mathrm{E}$, coll. G. Srinivasan, Reg. No. IV/2313/APRC/ZSI. One female, 12.xi.2005, East Kameng District, Arunachal Pradesh, India; Khari I.B, Seijosa, Pakke Tiger Reserve, Coll. G. Srinivasan, Reg. No. IV/2314/APRC/ZSI. One female, 12.xi.2005, East Kameng District, Arunachal Pradesh, India; Khari I.B, Seijosa, Pakke Tiger Reserve, coll. G. Srinivasan, Reg. No. IV/2315/APRC/ZSI. One

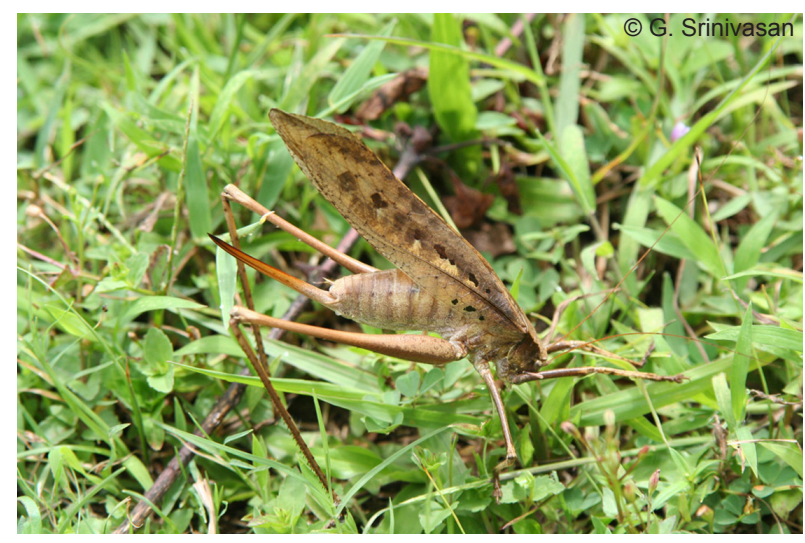

Image 9. Mecopoda elongata elongata (Linnaeus, 1758) female, 21.x.2007, Papumpare District, Arunachal Pradesh, India; ZSI Quarters main gate, Itanagar, coll. G. Srinivasan, Reg.No. IV/2316/APRC/ZSI.

Diagnosis: Body very large; fastigium wide, not surpassing the antennal sockets; vertex blunt; head more or less rounded; antennae strongly margined; Pronotum divided into three parts by two transverse sulci, narrowed anteriorly, granulated; anterior margin concave; posterior margin convex; posterior end of pronotum almost double the width than the anterior region. Prosternum with a pair of long spines. The lateral lobes of meso and meta sternum rounded anteriorly and bifurcated posteriorly in the middle. Wings fully developed; Tegmen surpassing hind knees; subcosta sharply sinuate just beyond the middle; Hind wings caudate. Post femora and tibiae very long and large; All other legs are long and slender. Post femora armed both externally and internally on the ventral side. Legs with the following number of spines on ventral margins: profemur and mesofemur smooth, postfemur with six large external and eight large internal, protibia with 10 small external and 11 small internal, mesotibia with 10 small external and 10 small internal, posttibia with 15 minute external and 15 minute internal. All tibiae with ventro-apical spurs and dorso-apical spurs on their margins. Femur of all the legs smooth on their dorsal side. Femora of all the legs smooth and indentate. Tibiae of all Legs with the following number of spines on dorsal margins: Protibia with eight minute external and five minute internal, mesotibia with 11 small external and nine small internal, posttibia with 23 small external and 23 small internal spines. Ovipositor long and straight. Male subgenital plate developed conically from region of bifurcation; ovipositor straight being slightly narrowed at apex. Tibial tympana opened on both the sides.

Colouration: Female: Brown to dry leave colour. Tegmina with 4-6 black and white spots in the middle. Lateral lobes of pronotum dark-brown at least on upper margin. Male: Green in colour. Tegmina with 4-6 white spots in the middle. Tip of spines on the legs are dark brown to black in both the sexes.

Measurements (in mm): Total Length 75-83; Body 26-31; Fastigium 3-3.5; Pronotum7-10; Tegmen 6675; Profemur 11-18; Mesofemur 15-19; Postfemur 53-56; Protibia 11-18; Mesotibia 15-20; Posttibia 54-56; Ovipositor 26-35. 
Distribution: India: Andaman \& Nicobar Islands, Andhra Pradesh, Arunachal Pradesh, Assam, Himachal Pradesh, Karnataka, Madhya Pradesh, Maharashtra, Manipur, Meghalaya, Mizoram, Nagaland, Odisha, Sikkim, Tamil Nadu, Tripura, Uttar Pradesh and West Bengal; Aru Islands; Australia; Celebes; China; Indonesia: Borneo, Sunda Islands; Japan, Malaca; Malaysia; Moluccas; New Guinea; Philippines; SIngapore; Taiwan; Thailand; Tonkin.

Remarks: Barman \& Srivastava (1976) reported this species from Kameng and Siang districts of Arunachal Pradesh.

\section{Subfamily: Listroscelidinae}

Genus Hexacentrus Serville, 1831

10. Hexacentrus unicolor Serville, 1831 (Image 10)

1831. Hexacentrus unicolor, Serville, Ann. Sci. nat. 22(86): 146. Syntype, Type locality: Asia-Tropical, Malaysia, Jawa; BMNH, London.

1838. Locusta unicolor, Serville, Histoire naturelle des insects. Orthopteres 531.

1891. Hexacentrus unicolor, Redtenbacher, Verh. Der Zoologisch-Botanischen Gesellsch. Wien 41:548, 552.

1893. Hexacentrus unicolor, Brunner Von Wattenwyl, Ann. Mus. Civ. Stor. Nat. Genova 213(33): 181.

1897. Hexacentrus unicolor, Griffini, Misc. Entom. 5911-120: 140.

1906. Hexacentrus unicolor, Kirby, A Synonymic Catalogue of Orthoptera (Orthoptera, Saltatoria, Locustidae Vel Acrididae) 2: 287.

1912. Hexacentrus unicolor, Karny, Genera Insectorum 131: 16.

1915. Hexacentrus unicolor, Karny, Supplementa Entomologica 4: 74.

1922. Hexacentrus unicolor, Hebard, Proc. Acad. Nat. Sci. Philad. 74: 269.

1923. Hexacentrus unicolor, Karny, Jour. Roy. Asiat. Soc. Malay. Branch 1: 182.

1926. Hexacentrus unicolor, Karny, Jour. Fed. Malay. States mus. 13(2-3): 144.

1927. Hexacentrus unicolor, Caudell, Proc. U.S. Nation. Mus. 71(3): 1-42.

1929. Hexacentrus unicolor, Bei-Bienko, Ann. Mag.nat. Hist. 104: 543.

1931. Hexacentrus unicolor, Karny, Treubia 12 (Suppl.): 95.
1933. Hexacentrus unicolor, Willemse, C, mem. Mus. r. hist.nat. Belgique 4(8): 17.

1935. Hexacentrus unicolor, $\mathrm{Wu}$, Catalogus Insectorum Sinensium (Catalogue of Chinese insects) 103.

1936. Hexacentrus unicolor, Tinkham, Lingnan Sci. J. 15 (2): 213.

1939. Hexacentrus unicolor, Ebner, Lingnan Sci. J. 18: 297.

1941. Hexacentrus unicolour, Furukawa, Zool. Mag. 53(7): 368.

1943. Hexacentrus unicolor, Tinkham, notes Ent. Chinoise 10(2): 51.

1986. Hexacentrus unicolor, Heller, J. Exp. Biol. 126: $97-109$.

1986. Hexacentrus unicolor, Inagaki, Matsuura \& T. Sugimoto, Comptes rendus des séances de la societe de biologie et de ses filiales 180(5): 589-592.

1990. Hexacentrus unicolor, Ingrisch, Senckenbergiana Biologica 70(1-3): 128.

1990. Hexacentrus unicolor, Lee, Insecta Koreana 7: 108 .

1998. Hexacentrus unicolor, Ingrisch \& Shishodia, Mitt. Schweiz. Ent. Gesellsch. 71(3-4): 370.

1998. Hexacentrus unicolor, Warchalowska: Siwa, Folia biologica (Krakow) 46: 161.

2000. Hexacentrus unicolor, Ingrisch \& Shishodia, Mitt. Munch. Ent. Ges. 90: 35.

2001. Hexacentrus unicolor, Ingrisch \& Garai, Esperiana 8: 756.

2001. Hexacentrus unicolor, Kim \& Kim, Korean J. Entomol. 31(3): 162.

2004. Hexacentrus unicolor, Shishodia \& Barman, Zool. Surv. India, State Fauna Series, Fauna of Manipur, 10 (2): 142.

2005. Hexacentrus unicolor, Wang, Jianfeng \& Shi, Acta Entomol. Sin. 48(2): 243.

2006. Hexacentrus unicolor, Shishodia, Zool. Surv. India, State Fauna Series, Fauna of Nagaland, 12: 92.

2007. Hexacentrus unicolor, Storozhenk \& Paik, Orthoptera of Korea, 60.

2010. Hexacentrus unicolor, Tan, Nature in Singapore, 3: 73, 79 (photos).

2010. Hexacentrus unicolor, Tan, Nature in Singapore, 3: 246, 262. (photos).

Material examined: One female, 20.x.2004, Papumpare District, Arunachal Pradesh, India; ZSI 


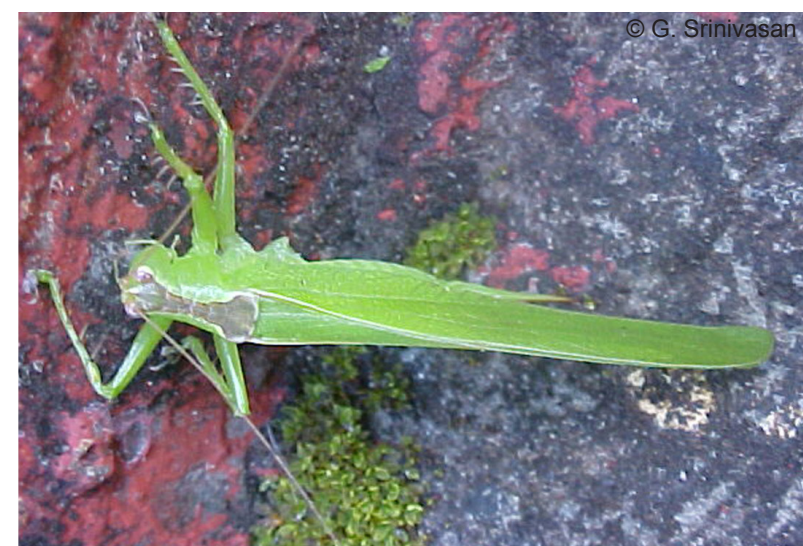

Image 10. Hexacentrus unicolor Serville, 1831

Quarters main gate, Itanagar, 2705'-35072'N \& 93037'30ํํㄹ'E, coll. G. Srinivasan, Reg No. IV/2317/APRC/ ZSI. One fmale, 10.x.2005, Papumpare District, Arunachal Pradesh, India; Itanagar Zoological Park, Itanagar, 26030’ N-29030’ $\mathrm{N} \& 9^{0} 30^{\prime} \mathrm{E}-97^{0} 30^{\prime} \mathrm{E}$, coll. G. Srinivasan, Reg. No. IV/2318/APRC/ZSI.

Diagnosis: Fastigium verticis narrow, conical, apex acute. Pronotum longer than broad, disc concave in anterior and posterior area, anterior margin of paranota rounded and the posterior margin angulated; there are three sulci found on the disc; the upper one is ' $U$ ' shaped, the middle one is transverse, straight and the lower one is in an inverted ' $U$ ' shaped. Pro, meso and meta sternum are each provided with a pair of spikelike processes. Tegmen surpassing hind knees; radius sector branching at the hind portion of the tegmen, forked, stem of radius with three more branches. Hind wing caudate. Anterior coxa without spine. Anterior femur slightly compressed. Knee lobes of pro and meso femur are smooth. Legs with the following number of opposing spines on ventral margins: pro and meso femur smooth. Left Protibia with six long, external and five long, internal and right protibia with five long, external and six long, internal spines on each margin; mesotibia with six long, external and five long, internal spines; hind knee lobes with a spine on each side; hind femora with widely spaced big spines and between them lie small spines; hind tibiae with small spines on dorsal and ventral face externally and internally. Epiproct triangular, apex obtuse. Cerci conical, apex pointing. Subgenital plate triangular, with a slight medial furrow apex obtuse. Ovipositor falcate, broad at base and pointed at apex, margins smooth. Tibial tympana closed on both the sides.
Colouration: General colour green. A special dark brown coloured band covers the pro, meso and metanotum.

Measurements (in mm): Total Length 48; Body 20; Fastigium 2.5; Pronotum 6.5; Tegmen 40; Profemur 8.5; Mesofemur 9.5; Postfemur 22; Protibia 8.5; Mesotibia 10; Posttibia 21; Ovipositor 10.2.

Distribution: India: Andaman \& Nicobar Islands, Arunachal Pradesh, Himachal Pradesh, Manipur, Mizoram, Nagaland and Sikkim; Celebes; China; Indonesia: Borneo and Sumatra; Japan; Malaysia; Moluccas; Myanmar; Philippines; Singapore; Taiwan; Thailand.

Remarks: New record for Arunachal Pradesh.

\section{Summary}

Totally 10 species of tettigoniids are discussed in this paper. Among them nine species are new records to the state of Arunachal Pradesh and five species are reported for the first time from India.

\section{REFERENCES}

Barman, R.S. (2003). Insecta: Orthoptera: Tettigoniidae. Zoological Survey of India, Fauna of Sikkim, State Fauna Series 9(2): 193-201.

Barman, R.S. \& G.K. Srivastava (1976). On a collection of Tettigoniidae (Insecta) from Arunachal Pradesh, India, Zoological Survey Newsletter 2(3): 93-94.

Heller, K.G. (1995). Acoustic signaling in palaeotropical bushcrickets (Orthoptera, Tettigonioidea, Pseudophyllidae): does predation pressure by eavesdropping enemies differ in the palaeotropics and neotropics. Journal of Zoology 237: 469-485.

Kulkarni \& M.S. Shishodia (2005). Insecta: Orthoptera. Zoological Survey of India, Fauna of Melghat Tiger Reserve, Conservation Area Series 24: 324.

Otte, D. (1997). Tettigonioidea. Philadelphia: Academy of Natural Sciences. Orthoptera Species File. 7.

Rentz, D.C.F. (1979). Comments on the Classification of the Orthoptera Family Tettigoniidae, with a key to Subfamilies and description of two New Subfamilies. Australian Journal of Zoology 27: 991-1013.

Senthilkumar, N., N.D. Barthakur \& N.J. Borah (2006). Fauna of Protected Areas - 29. Orthopteran fauna of the Gibbon Wildlife Sanctuary, Assam. Zoos' Print Journal 21(8): 2347-2349.

Senthilkumar (2010). Orthopteroids in Kaziranga National Park, Assam, India. Journal of Threatened Taxa 2(10): 1227-1231.

Shishodia, M.S. (2000). Short and Long-horned grasshoppers 
Key to the subfamilies of the family Tettigoniidae of Arunachal Pradesh

1. Male subgenital plate with a pair of styles; first two tarsi grooved laterally ..... Male subgenital plate without style; first two tarsi without groove laterally. Phaneropterinae

2. Fore tibia with short immovable spines on its ventral margins

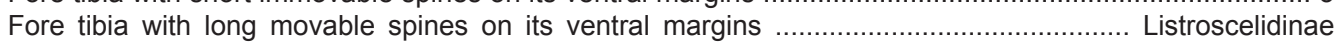

3. Tibial auditory structure opened on both the sides ......................................................... Mecopodinae

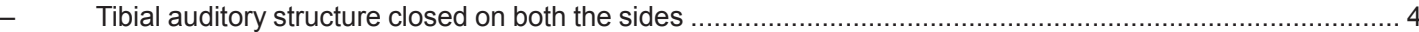

4. The mouth of the tibial auditory structure is slit-like on both the sides ................................ Conocephalinae

- $\quad$ The mouth of the tibial auditory structure is wide on both the sides ........................... Pseudophyllinae

Key to the genera of the subfamily Phaneropterinae from Arunachal Pradesh

1. Fastigium verticis slightly surpassing the rim of the antennal scrobae. Disc of pronotum smooth. Post tibia bears simple spines Khaoyaiana Ingrisch.

2. Fastigium verticis distinctly surpassin the rim of the antennal scrobae. The pronotal disc margins expands like armour with the lateral carinae denticulated. Post tibia bears sickle-shaped spines TrachyzulphaDohrn.

Key to the genera of the subfamily Pseudophyllinae of Arunachal Pradesh

1. Fastigium verticis not surpassing the rim of antennal scrobae Phyllozelus Redtenbacher

- $\quad$ Fastigium verticis surpassing the rim of antennal scrobae Pseudophyllus Serville.

2. Fastigium verticis surpassing well beyond to the rim of the antennal scrobae Fastigium verticis surpassing slightly beyond the rim of antennal scrobae

3. Fastigium verticis blunt, and the apex far to the rim of antennal scrobae..... Fastigium verticis obtuse and the apex near to the rim of antennal scrobae

Chloracris Pictet \& Saussure

Key to the genera of the subfamily Conocephalinae of Arunachal Pradesh

1. Fastigium short, as long as broad; apex of the fastigial vertex blunt, rounded. Protibia with 6 external and 6 internal spines on its ventral margins

Euconocephalus Karny.

Fastigium long and conical, narrowing towards the tip; apex of the fastigial vertex acute. Protibia with 5 external and 7 internal spines on its ventral margins Pyrgocorypha Stal.

and Crickets of Bastar district, Madhya Pradesh, India. Records of Zoological Survey of India 8(1): 27-80.

Shishodia, M.S., A. Dey \& S.K. Tandon (2003). Insecta: Orthoptera: Acridioidea and Eumastacoidea. Zoological Survey of India, Fauna of Sikkim, State Fauna Series 7(2): 165-192.

Shishodia, M.S. \& S.K. Tandon (2000). Insecta: Orthoptera: Acridioidea and Eumastacoidea. Zoological Survey of India, Fauna of Tripura, State Fauna Series 7(2): 197-230.

Shishodia, M.S., K. Chandra \& S.K. Gupta (2010). An Annotated Checklist of orthoptera (Insecta) from India. Records of Zoological Survey of India, Occasional paper No. 314: 283-324.
Author Contribution:

The Study: GS has done the Survey, Field photography, collection and the preservation of the specimens. DP has assisted in the preparation of the manuscript. Current paper: GS has done identification, preparation of various identification keys. DP has also assisted in preparation of the identification keys and the manuscript. 